\title{
Experimental Study to Reinforce The Weak Subgrade Soil for Low-Volume Roads by Coir Geotextile Mats
}

\author{
D Harinder ${ }^{1} *$, S. Shankar ${ }^{2}$ \\ ${ }^{1}$ National Institute of Technology, Warangal, India.
}

* Corresponding author: hariatnitw @gmail.com

Tel.: +918106857040

Received: Nov 08, 2017. Revised : Feb 15, 2018, Accepted: Feb 26, 2018, Published: 1 March 2018

DOI: 10.24273/jgeet.2018.3.01.882

\begin{abstract}
The construction and maintenance of pavement over the weak subgrade soil become the challenging task to the pavement engineering. One of the major reasons of subgrade failure of pavement is weak subgrade. The weak subgrade soil noticed a Black Cotton (BC) soil. The BC soil subgrade poses several serious problems to the pavement such as rutting, fatigue, reflecting crack and undulation of the pavement. To minimize this problem of pavement, there are many conventional stabilization techniques were adopted and reported. But these techniques are not applied effectively into the pavement to stabilize the weak subgrade. To address this problem, to give the additional strength to the pavement geosynthetics are taken as alternate material for stabilization of pavement. In the present study, an attempt is made in the laboratory with four types of coir mats by using the fabricated mould. The study is conducted in the form of two-layer pavement system. The pavement model layer is prepared as subgrade and sub-base with BC soil and sandy gravel soil respectively. The prepared fabricated mould is tested by using the Wheel Tracking Test (WTT) under moving traffic loading condition. This study concluded that the suitable placement position and the types of coir mats can be affect the performance of the LVRs. It's also noticed that the suitable coir mats can effectively reduce the deformation, so that it can be used over the weak subgrade to improve the performance of the LVRs.
\end{abstract}

Keywords: Coir mats, Reinforcement, Separation, Subgrade, Sub-base, WTT.

\section{Introduction}

The performance of the roads largely depends on the properties and types of soil for the construction pavement. The larger numbers of factors are affecting the service life and maintenance of the pavement. This includes the environmental factors, traffic loading, ageing and properties of the subgrade. How're, the BC soil is occupied in large area of the country. The BC soil subgrade poses several problems to the roads in the form of rutting, fatigue, reflecting, and uneven or undulation in pavement structure. In this case, particularly the replacement of subgrade soil or to stable the weak subgrade is necessary to provide the stable pavement. But due to local constraint, the adoptions of both the techniques are unsuitable. In a particular case, alternate, past construction and stable locally available materials become necessary in pavement engineering. In view of the above consideration, an alternate material such as geosynthetics are used in pavement application to provide the additional strength and improve the performance of the weak subgrade. The use of geosynthetics in pavement application have been starting form early 1970's, many of the studies were conducted on the pavement using the polymeric materials. Few of the studies were also adopted with natural geotextile in pavement application. The uses of geotextile in pavement application are gain governing promises entire the world, due to their function and easy installation process over the weak subgrade. The function of geotextile are reinforcement, separation, drainage and filtration help in settling the pavement, provide additional strength and improved the service life of the pavement. In view of the above associate problem and benefits with geotextile, an attempt is made in the laboratory to evaluate the performance of the coir mats and its benefits to the pavement by conducting WTT under moving load condition.

The present study is conducted with the four types coir geotextile are coir composite (CC), geogrid + non-woven coir mat (GG+NWCM), woven coir mats (WCM) and non-woven coir mats to the reinforcement of weak subgrade for LVRs. The test was conducted using the fabricated mould size are $300 \mathrm{~mm} \times 300 \mathrm{~mm} \times 200 \mathrm{~mm}$ and $300 \mathrm{~mm} \times$ $300 \mathrm{~mm} \times 300 \mathrm{~mm}$. The samples are prepared in the fabricated mould with BC soil as subgrade and sandy gravel as sub-base soil (two-layer pavement section) with varying thickness of pavement layer as per the modified CBR test protocol. The sample was tested using the WTT apparatus under moving load condition. 


\section{Geosynthetics}

The problem of pavement generally associated with the strength of the subgrade and sub-base soil. The construction of pavement over the soft soil, clay soil, and silt soil poses several problems to the pavement, in the form of rutting and fatigue, reflection cracks and uneven surface of the pavement (Rao, 2000; Brian, 2001; Rama, 2010). This problem occurs due to its high swelling, shrinkage, settlement characteristic and also volume change behaviour of BC soil (Yang, 2007) during various seasons under the dry and wet condition. To prevent these problems, many of the conventional techniques were adopted and restrict the problem of pavement. But these conventional methods are not eco-friendly neither economical for the construction of pavement and also difficulties during the construction of pavement in the field such as mixing of soil, compaction etc. to overcome with this problem, geosynthetics are taken as alternate materials is used in pavement construction from the past four decades.

During the past few decades, geosynthetics have gained universal attention across all over the world, the possible types of soil subgrade either to overcome the subgrade deficiency or enhance permanent life and performance (Al-Qadi et al 2008; Jersey et al, 2012;; Khodaii et al, 2008 and Zornberg et al, 2009). The geotextile acts a tension member and reduce the deformation and the vertical stress over the subgrade (Giroud and Noiray, 1981) and improve the performance of the roads. The maximum tension effect is available to decrease the bearing capacity of the pavement when the uses of woven and non-woven coir mats are placed over the interface (Babu, 2007). The presence of the geosynthetics layer in the pavement system increase the later system and stiffness of the base/sub-base material while reducing the vertical stress and deformation of the subgrade (Perkins, 1999) are reported. One of such applications can be in the unpaved road over soft subgrade where the rate of plastic deformation due to repeated traffic loads is faster during the initial stage and gets stabilized later (Fannin and Sigurdsson, 1996). Various investigators stress the high cost of geosynthetics and stringent environmental protection requirements make it important to explore alternative natural products to make the constructions cost-efficient and ecofriendly (Sarsby, 2007; Chauhan, 2008). The study investigated that the polymeric geocell improves the performance of the unpaved roads over the poor subgrade, quarry dust shown the better performance than the other materials (Pokhaerl 2011). To Studied the performance of the geogrid reinforcement, indicates that the use of Geosynthetics in pavement over the poor subgrade soil tends to reduce the Sub Base thickness with increasing traffic volume (Charles, 2014). To addressing the problem of pavement, to prevent this problem this study examines the coir geotextile mats can effectively serve as reinforcement, separation, drainage materials over the weak subgrade soil for LVRs. The study is conducted under moving loading condition in the laboratory, to correlate laboratory study with the field study using the accelerated pavement test track (APT).

\section{Materials}

The subgrade soil consists of clay having a Liquid Limit (LL) of $58 \%$ and Plastic Limit (PL) of $27 \%$ The clay is classified as $\mathrm{CH}$ as per Indian Standards and had a specific gravity of 2.62. Optimum Moisture Content (OMC) and Maximum Dry Density (MDD) was obtained as $17 \%$ and 17 $\mathrm{kN} / \mathrm{m} 3$ respectively in standard Proctor test. The soaked California Bearing Ratio (CBR) value obtained is 1 for $\mathrm{CH}$ soil.

Table 1. The basic properties of the coir geotextile

\begin{tabular}{lc}
\hline The Properties of the coir & Values \\
\hline Length $(\mathrm{mm})$ & $15-30$ \\
Density (g/cc) & $1.14-1.41$ \\
Breaking elongation (\%) & 27 \\
Diameter (mm) & $0.1-1.5$ \\
Specific Gravity & 1.12 \\
Modulus of elasticity (GPa) & 8.14 \\
Water soluble (\% & 5.20 \\
\hline
\end{tabular}

Similarly, the sub-base materials are sandy gravel were used. The properties of these materials are Optimum Moisture Content $(\mathrm{OMC}=8.0)$, Maximum Dry Density (MDD $=18.7 \mathrm{kN} / \mathrm{m} 3)$, shear parameter $(C=0$ and $(=-310)$. The soaked and unsoaked California Bearing Ration (CBR) is 6 and 13 are presented respectively. The four types of coir mats were used in the study. The properties of the coir geotextile mats are given in tablel. The types of coir geotextile used in the study shown in the below Fig. 1. The notations of the coir geotextile as follow: $\mathrm{CC}=$ Coir Composite, $\mathrm{WCM}=$ Woven Coir Mat.

The mechanism of coir geotextile mats over the weak subgrade as shown in Fig. 2. The conventional pavement load distribution characteristics and separation of two-layer material are shown. The Fig 2B shown the reinforcement and separation of layer material, without possibility of intermix with the composite mats. 

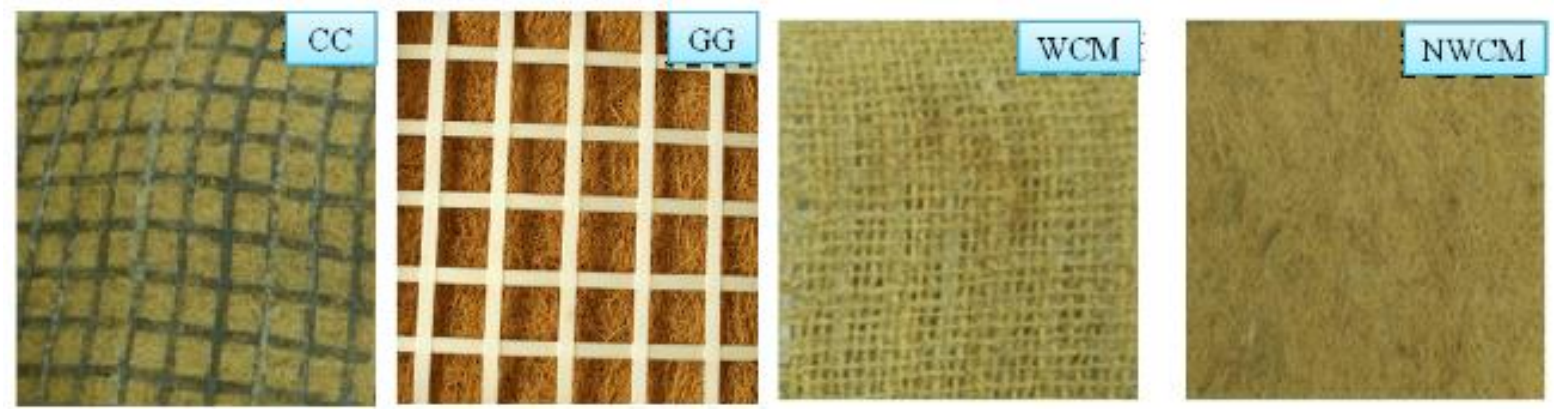

Fig. 1. Types of coir geotextile mats used in the study

Similarly lower the reinforcement and improper mixing of two-layer material is given in Fig 2C. The CC and GG+NWCM significantly reduce the settlement and also effectively work to possess the separation function than the WCM. The WCM gives the less reinforcement than the CC and GG+NWCM and also in sufficient to give the separation function due to its opening mesh size.

\section{Experimental Setup}

The Wheel Tracking Test apparatus (WTT) are used for this investigation with varying contact pressure of moving load to simulate the field condition. It was developed by British National Rail
Road Research Institute (Generally used for measuring the plastic deformation of bituminous asphalt concrete). The WTT apparatus height of the loading lever has been raised using the fabricated angle sections. The fabricated angles are controlling the enable to the loading onto pavement model section. The maximum load applied on to the pavement has $55 \mathrm{Kg}$, through the moving wheel of diameter $200 \mathrm{~mm}$, width of $50 \mathrm{~mm}$ made of solid rubber. To run the wheel over the model section three phase motor with $75 \mathrm{kw}, 400 \mathrm{v}$ power motor is used. The experimental setup is shown in Fig. 3.

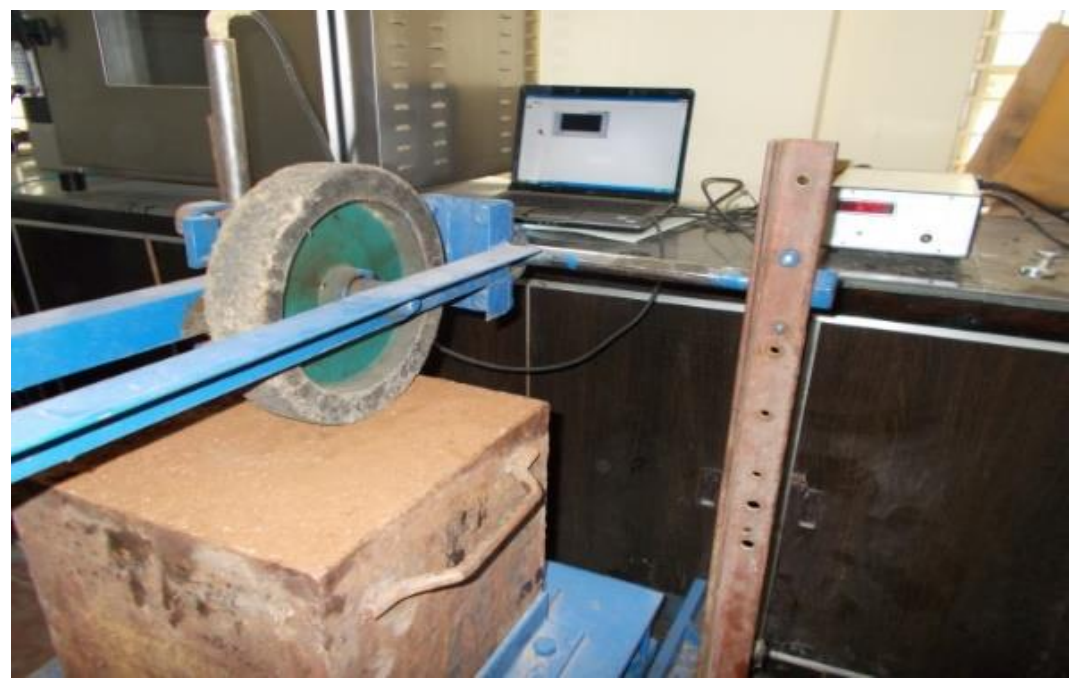

Fig.3. Experimental setup with the data accusation system

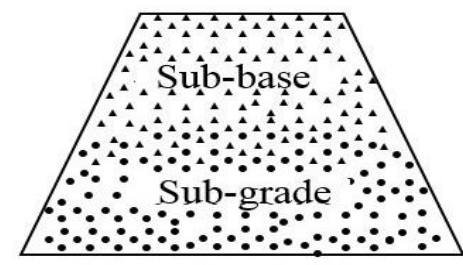

Separation function without Coir mat

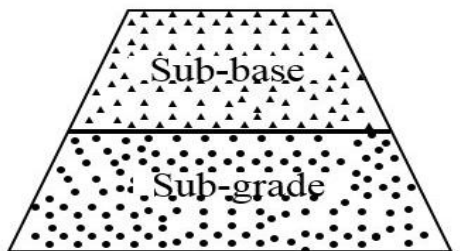

Separation function with

Non-Woven Coir mat

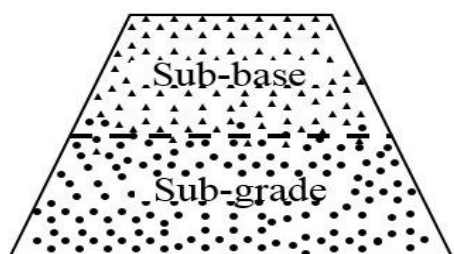

Separation function with Woven Coir mat

Fig. 2. Mechanisms of Coir Geotextiles 


\section{Result and Conclusion}

In the laboratory, the model pavement layers were prepared as two-layer pavement system. The pavement layer was prepared as subgrade and subbase with and without placement of coir mats between the subgrade and sub-base layer (reinforcement and un-reinforcement of coir geotextile mats). The subgrade as a BC soil and the sub-base as a sandy gravel soil are prepared and compacted in the fabricated mould of size thickness as $200 \mathrm{~mm}$. As shown in above Table 2 the maximum and the minimum number of wheel passes are variable, the number of wheel passes depends on the position of the coir mats and also the types of the coir geotextile. The maximum number of wheel passes (800) at $40 \mathrm{~mm}$ rut depth was found at the $\mathrm{H} / 4$ position with reinforcement of CC. The varying thickness of subgrade and sub- base with and without reinforcement of coir mats along with rut depth and wheel passes also are given in Table 2 with sandy gravel sub-base soil.

In the laboratory study, the placement of coir mats at $\mathrm{H} / 2$ position the number of wheel passes with sandy gravel sub-base soil and without provision of the coir mats. From the study it was observed that the higher repetition is occurs with (GG+NWCM) at H/4 position compared with other types of coir geotextile mats. It was also noticed that the performance of the coir mats are uniform due to placing of higher thickness of sub-base soil. The repetition were found at $\mathrm{H} / 2$ position is occurs due to the sub-base soil, the failure are notice in sub-base soil due to lower shear strength and CBR values. Fig. 3 shows the rut depth and a number of wheel passes at the $\mathrm{H} / 2$ position of sandy gravel soil.

Table 2 Pavement Component Layers with Variable Thickness of Subgrade (BC) and Sub-Base (Sandy Gravel) with and without Coir Geotextile.

\begin{tabular}{llllc}
\hline S.NO & $\begin{array}{l}\text { pavement model section with } \\
\text { 300 mm } \times 300 \mathrm{~mm} \times 200 \mathrm{~mm}\end{array}$ & $\begin{array}{l}\text { Position of } \\
\text { Coir Mats }\end{array}$ & $\begin{array}{l}\text { Absorb } \\
\text { depth }(\mathrm{mm})\end{array}$ & $\begin{array}{l}\text { Number of } \\
\text { wheel pass }\end{array}$ \\
\hline 1 & BC-SG & & 40.0 & 280 \\
2 & BC-SG-CC & $\mathrm{H} / 2$ & 40.0 & 350 \\
3 & BC-SG-GG-NWCM & 40.0 & 190 \\
4 & BC-SG-WCM & & 40.0 & 290 \\
5 & BC-SG-NWCM & & 40.0 & 150 \\
\hline 6 & BC-SG & & 40.0 & 300 \\
7 & BC-SG-CC & H/3 & 40.0 & 390 \\
8 & BC-SG-GG+NWCM & & 40.0 & 430 \\
9 & BC-SG-WCM & & 40.0 & 350 \\
10 & BC-SG-NWCM & & 40.0 & 300 \\
\hline 11 & BC-SG & H/4 & 40.0 & 290 \\
12 & BC-SG-CC & & 40.0 & 800 \\
13 & BC-SG-GG+NWCM & & 40.0 & 650 \\
14 & BC-SG-WCM & & & 580 \\
15 & BC-SG-NWCM & & & 270 \\
\hline
\end{tabular}

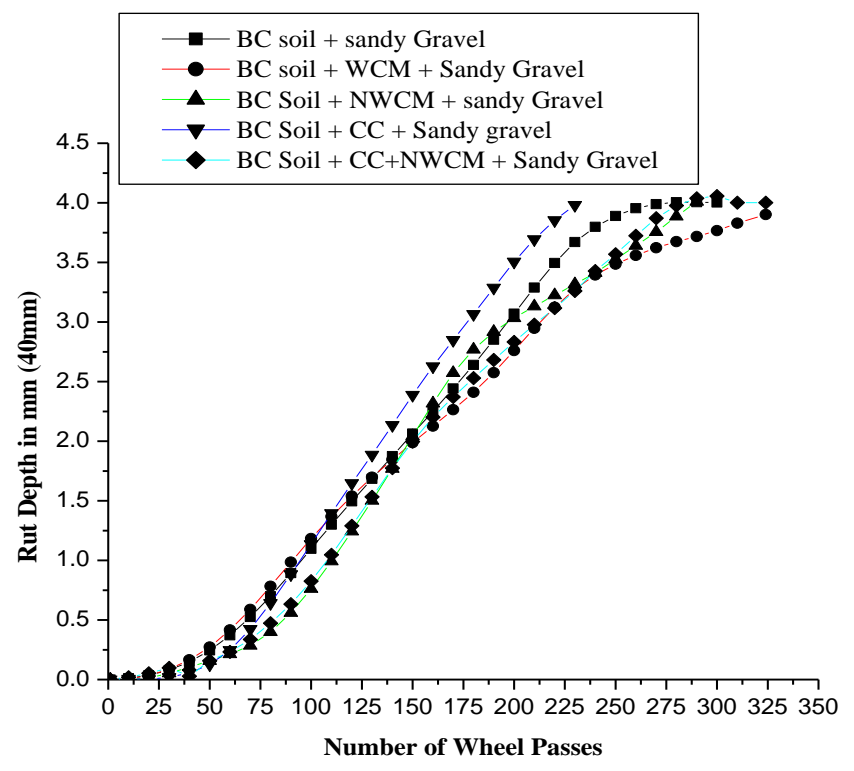

Fig. 3. Rut depth along with number of wheel passes at $\mathrm{H} / 2$ position coir mats. 
The provision of coir mats at $\mathrm{H} / 3$ position in between subgrade and sub-base shown the differentiate in number of wheel passes depth for same rut depth. The woven coir mats increase the rut depth due to the higher thickness of coir mat than the woven coir mat. The provided coir mats at $\mathrm{H} / 3$ position taken the maximum load than the $\mathrm{H} / 2$ position with coir composite materials. The coir composite material possesses the reinforcement and separation functions to the subgrade and reduces the deformation of the pavement structure. The coir geotextile mats are ensured the multi-function in pavement application such as reinforcement, separation, and drainage (Ali khodii Imadi, 2009). The number of wheel passes and rut depth at $\mathrm{H} / 3$ position is showed in Fig. 4.

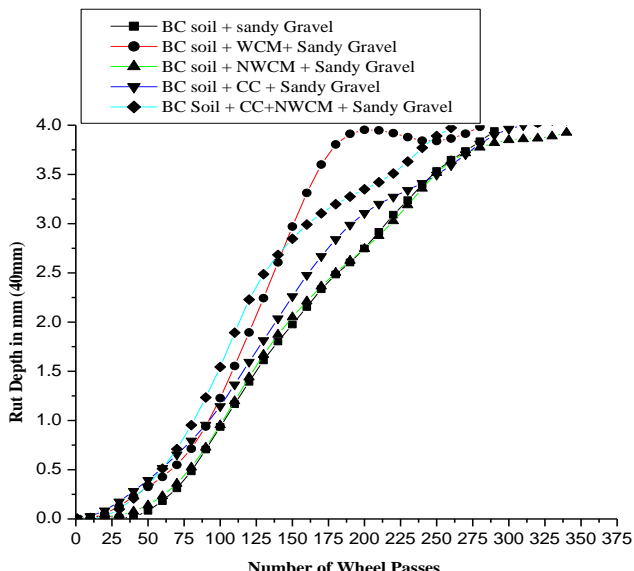

Fig. 4. Rut depth and number of wheel passes at $H / 3$ position of SG soil

The two-layer pavement model section was prepared with the incorporation of coir geotextile at the $\mathrm{H} / 4$ position in order to reduce the sub-base soil materials. During the laboratory study it seen that the higher repetition are found at $\mathrm{H} / 4$ position than the $H / 2$ and $H / 3$ position, the placement of coir mats at $\mathrm{H} / 4$ position performed as a reinforcement material than the $\mathrm{H} / 2$ and $\mathrm{H} / 3$ position, and transferred the load towards the edge of the pavement. The placement of coir mats at $\mathrm{H} / 4$ position with reducing the sub-base thickness is showed the better performance due to its tension membranes act immediately due to placing near to the tire load from the top of the sub-base. The rut depth and number of wheel passes at $\mathrm{H} / 4$ position is shown in Fig. 5.

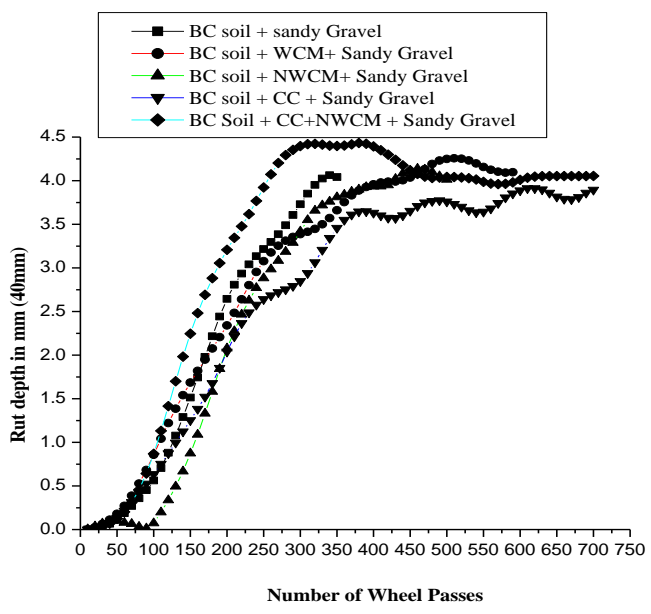

Fig. 5. Rut depth and Number of wheel passes at $h / 4$ position of SG soil

The laboratory study is performed to evaluate the effectiveness of coir mats with fabricated mould of size $300 \mathrm{~mm} \times 300 \times 300 \mathrm{~mm}$. the study were conducted as a two-layer pavement system with and without provision of coir mats at $\mathrm{H} / 2, \mathrm{H} / 3$ and $\mathrm{H} / 4$ position in between subgrade and subbase layer tested by using the WTT apparatus. The deformation of fabricated mould are noted with respective their number of wheel passes. The placement of coir mats, rut depth along with the number of wheel passes are given in table 3 .

From the table 3 it was notice that the high number of repetition was found at $\mathrm{H} / 2$ position by using the CC and GG+NWCM coir geotextile with higher thickness of sub-base soil with same rut depth. The lower number of wheel passses were noticed with reinforcement of NWCM at $\mathrm{H} / 3$ position. the reinfoced with CC and GG+NWCM coir geotextile mats at $\mathrm{H} / 3$ position greatly reduced the deformation and sub-base thickness and increse the repetetion 1040 and 1160 respectively.

Table 3 Pavement Component Layers with Variable Thickness of Subgrade (BC) and Sub-Base (Sandy Gravel) with and without Coir Geotextile.

\begin{tabular}{clccc}
\hline S.NO & $\begin{array}{l}\text { pavement model section with } \\
\text { 300mmx300mmx300mm }\end{array}$ & $\begin{array}{c}\text { Position of } \\
\text { Coir Mats }\end{array}$ & $\begin{array}{c}\text { Absorb Rut } \\
\text { depth }(\mathrm{mm})\end{array}$ & $\begin{array}{c}\text { Number of } \\
\text { wheel pass }\end{array}$ \\
\hline 1 & BC-SG & & 40.0 & 670 \\
2 & BC-SG-CC & & 40.0 & 1400 \\
3 & BC-SG-GG+NWCM & H/2 & 40.0 & 1500 \\
4 & BC-SG-WCM & & 40.0 & 948 \\
5 & BC-SG-NWCM & & 40.0 & 700 \\
\hline 6 & BC-SG & & 40.0 & 170 \\
7 & B-SG-CC & 40.0 & 420 \\
8 & BC-SG-GG+NWCM & H/3 & 40.0 & 480 \\
9 & BC-SG-WCM & & 40.0 & 356 \\
10 & BC-SG-NWCM & & & 190 \\
\hline
\end{tabular}




\begin{tabular}{clccc}
\hline S.NO & $\begin{array}{l}\text { pavement model section with } \\
\text { 300mm×300mm×300mm }\end{array}$ & $\begin{array}{c}\text { Position of } \\
\text { Coir Mats }\end{array}$ & $\begin{array}{c}\text { Absorb Rut } \\
\text { depth (mm) }\end{array}$ & $\begin{array}{c}\text { Number of } \\
\text { wheel pass }\end{array}$ \\
\hline 11 & BC-SG & & 40.0 & 345 \\
12 & BC-SG-CC & & 40.0 & 1040 \\
13 & BC-SG-GG+NWCM & & 40.0 & 1160 \\
14 & BC-SG-WCM & H/3 & 40.0 & 490 \\
15 & BC-SG-NWCM & & 40.0 & 408 \\
\hline
\end{tabular}

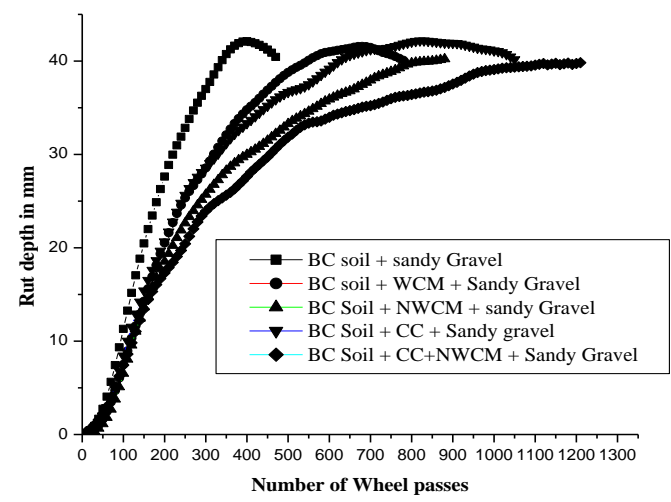

Fig. 6. Rut depth and number of wheel passes at $H / 2$ position of SG soil.

The un-reinforced pavement model layer system showed the lower repletion at $\mathrm{H} / 3$ position than the reinforced model layer, which is shown with block color trend line in fig. 6. The reinforcement of model layer with sandy gravel sub-base soil with at $\mathrm{H} / 2$ position showed the higher repetition than the $\mathrm{H} / 3$ and $\mathrm{H} / 4$ position. In this case, the sub-base soil thickness is increased than the other case such as $\mathrm{H} / 3$ and $\mathrm{H} / 4$ position. Due to this increased thickness of sub-base soil increase the repetition improved the performance of the pavement. The rut depth and the number of wheel passes with sandy gravel soil at $\mathrm{H} / 2$ position is shown in Fig. 6.

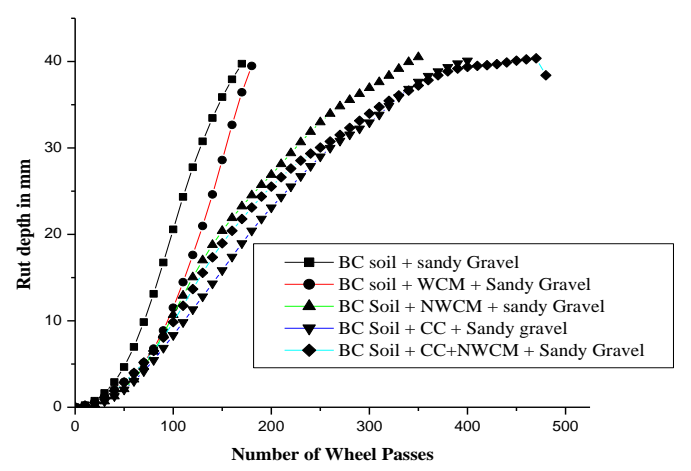

Fig. 7 Rut depth and number of wheel passes at $H / 3$ position of SG soil.

The provision of coir mats with lower strength of sub-base soil will causes failure pavement and reduce the performance of the coir geotextile and also the pavement. In this case, the placement of coir mat at $\mathrm{H} / 3$ position with the sandy gravel soil showed the lower repetition 170 with the unreinforcement model layer. The reinforcement with coir mats at $\mathrm{H} / 3$ position is also showed the less number of wheel passes 480 with GG+NWCM coir mats. It was found that the provision of coir geotextile mats at $\mathrm{H} / 3$ position with sandy gravel sub-base soil inappropriate to improve the performance of the pavement. The rut depth and number of wheel passes at $\mathrm{H} / 3$ position is shown in Fig. 7.

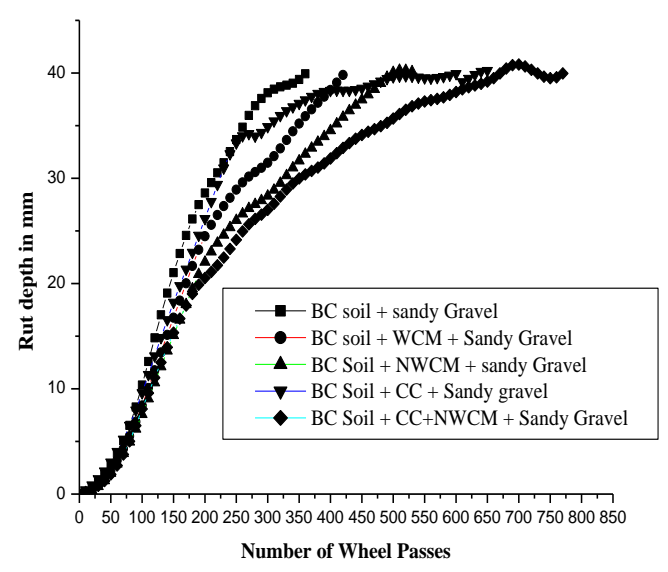

Fig. 8. Rut depth and number of wheel passes at $\mathrm{H} / 4$ position of SG soil.

The reinforcement of pavement model-layer system with four type of coir mats at $\mathrm{H} / 4$ position having the better reinforcement than the $\mathrm{H} / 3$ position with the sandy gravel sub-base soil. In this case the placed coir mats at $\mathrm{H} / 4$ position act as a tension member and the maximum load will take place by the coir mats. The thicknesses of coir mats also play key role to improve the load bearing capacity of the pavement. The higher the thickness of coir mats (CC, GG+NWCM, and NWCM) reduces the deformation. The thickness of coir mats gives the additional strength to the pavement, reduces the vertical deformation, help in slow setting of pavement with proper separation. The provision of coir mat at $\mathrm{H} / 4$ position, the rut depth and the number of wheel passes are shown in Fig. 8.

The laboratory study was performed to determine the performance of the geotextile with varying thickness of fabricated mould and evaluated the effectiveness of coir mats. The application and its utilization in LVRs. The maximum numbers of wheel passes occur at the $H / 3$ position with reinforcement of GG+NWCM. In this case, the woven coir geotextile mats act as a 
reinforcement material and the non-woven mats purely act as separation material. When the nonwoven coir mats attached with the geogrid it gives the additional reinforcement to the pavement structure. In addition to this, the coir geotextile acts as a separation and drainage material over the subgrade.

\section{Conclusions}

The results of the study have demonstrated the potential of coir geotextile in LVRs over the weak subgrade. This paper reviewed the concept of utilization of coir geotextile and it composite mats for LVRs.

Maximum repetitions are found with coir composite at $\mathrm{H} / 2, \mathrm{H} / 3$ and $\mathrm{H} / 4$ position in case of $200 \mathrm{~mm}$ thickness of the mould. In case of $300 \mathrm{~mm}$ thickness of mould higher repetition are obtained with CC and GG+NWCM at H/2 position as 1400 and 1500 respectively.

The CC and GG+NWCM coir mat shown the better reinforcement at $\mathrm{H} / 4$ position in both cases. The CC mats more significant to gives the reinforcement and separation of function to pavement and improved the performance.

The sub-base soil parameter such as $C$ and $\phi(0$ and $31^{\circ}$ ) play a key role to place the geotextile irrespective of the thickness of sub-base soil. The increase thickness of sandy gravel sub-base soil increase the repetition later its fails due to the improper shear strength.

The NWCM mats are more significant in term of reinforcement and separation than the WCM. The higher thickness of coir mats (NWCM) more effecting to reduce the deformation over the weak subgrade.

\section{References}

Rao, Subba, K.S. 2000. Swell-Shrink Behaviour of Expansive Soils - Geotechnical Challenges. Indian Geotechnical Journal, 30 (1).

Brian, Albrecht, a., and Benson, Craig, H. 2001. Effect of Desiccation on Compacte Natural Clays. Journal of geotechnical and geo environmental engineering., (127),67-75.

Rama, Rao, M., and Srirama Rao, A. 2010. SwellShrink Behaviour of Expansive Soils Under Fly Ash Cushions. Indian Geotechnical Conference - 2010, GEOtrendz, IIT Bombay.

Yang, S. H., and Al-Qadi, I. L., 2007. Costeffectiveness of using geotextiles in flexible pavements. Geosynthetics International, 14, No, 1.

Al-Qadi, I.L., Dessouky, S., Tutumluer, E., and Kwon, J. 2011. Geogrid mechanism in low volume flexible pavements: accelerated testing of full-scale heavily instrumented pavement sections.Int. J. Pavement Eng., 12, (2), 121135.

Jersey, R. Sarah., tingle, S. Jeb., Norwood, J. Gregory., Jayhyun, Kwon. And mark Wayne. Full-Scale Evaluation of Geogrid-Reinforced thin
Flexible Pavements. Journals of the Transportation Research Board, Washington, D.C., 2012, pp.61-71.

Ferrotti, G., Canestrari, G., Virgili, A., and Grilli, A., 2011. A strategic laboratory approach for the performance investigation of geogrids in flexible pavements. Construction and Building Materials Pp: 2343-2348.

Ali khodii Imadi. L., Shahab Fallah.,Fereidoon, Moghadas., and Nejad., 2009. Effect of GeoSynthetic on Reflecting Cracking on Asphalt Overlay. Geotextile and Geomembranes. pp.18.

Zornberg, J. G., and Gupta, R., 2009. Reinforcement of pavements over expansive clay subgrades. Proceedings of the 17th International Conference on Soil Mechanics and Geotechnical Engineering.

Giroud, J.P., Noiray, L., 1981. Geotextile reinforced unpaved road design. Journal of Geotechnical Engineering ASCE 107 (9), 1233-1254.

Babu, K.K., 2007. Utilisation of coir geotextiles for unpaved roads and embankments Ph.D. thesis, Cochin University of Science and Technology, Kochi, India.

Perkins, S.W., 1999. Mechanical response of geosynthetic reinforced flexible pavements. Geosynthetics International 6 (5), 347-382.

Fannin, R.J., Sigurdsson, O., 1996. Field observations on stabilization of unpaved roads with geotextiles. Journal of Geotechnical Engineering ASCE 26 (7),544553.

Sarsby, R.W., 2007. Use of 'Limited Life Geotextiles' (LLGs) for basal reinforcement of embankments built on soft clay. Geotextiles and Geomembranes 25 (4-5), 302-310.

Chauhan, M.S., Mittal, S., Mohanty, B., 2008. Performance evaluation of silty sand subgrade reinforced with fly ash and fibre. Geotextiles and Geomembranes 26 (5), 429-435

Pokharel, Sanat Kumar, Jie Han., Manandhar, Chandra., Yang Xiaoming., Leshinsky, Dov., Halahmi Izhar., and Robert, L, parsons (2011). Accelerated pavement testing of geocellreinforced unpaved roads over the weak subgrade. Journal of transportation research board. No: 2204, PP. 67-75.

Charles, Anum Adams., Nana Yaw Amofa., and Richter Opoku-Boahen., 2014. Effect of geogrid reinforced subgrade on Layer thickness design of low volume bituminous sealed road pavements. International refereed Journal of engineering and science, Vol. 3 (7), PP. 59-67. 